\title{
Prof. Dr. Ahmet Demir Hocamızın Ardından...
}

\author{
Prof. Dr. Celal Göle \\ A.Ü. Siyasal Bilgiler Fakültesi Dekanı
}

Fakültemiz Dergisinin bu sayısının 5 Mayıs 2002 tarihinde aramizdan ayrtan Hocamiz Prof. Dr. Ahmet Demir'e armağan edilmesi bizleri hüzünlendiriyor, ister istemez çok üzüyor...

10 Nisan 1930 tarihinde Izmit'te doğan Hocamız, 1950 yılında Ankara Gazi Lisesi Fen Kolu'nu bitirmiş; Fakültemizden mezun olduktan sonra da Maliye Bakanltğı'na stajyer memur olarak girmiştir. Maliye Bakanlığı'nda stajını tamamladıktan sonra, 1956 yılında silah altına alınmış; terhisinden sonra ise bir Hollanda şirketinde iki ay için teknik ressam olarak çalışmış, 1957 yılında da tekrar Maliye Bakanlığı' ndaki görevine dönmüş̧ür.

Hocamız 1958 yılında Fakülttemizin Iktisadi Coğrafya Kürsüsü Asistanlı̆̆ı'na atanarak akademik kariyere atılmıştır.

1962 yılında, Fakültemizde, "Türkiye Iç Sularından Faydalanma" başlıklı tezini başarı ile savunarak "Maliye ve Iktisat Bölümü Doktoru" ünvantnt almıştır. Bu arada ikinci bir lisans eğitimi için Üniversitemizin Dil ve Tarih-Coğrafya Fakültesinde öğrenci olmuş, 1964 yılında da bu Fakülte'nin Iktisadi Coğrafya Bölümü'nden mezun olmuştur.

1960 yılında, "Su Kaynaklarının Geliştirilmesi" sorununu incelemek üzere Fransa'ya; 1965 yilında da "Iktisadi Kalkınma ve Sanayileşme" konusunu araştırmak; aynıca Iktisadi Coğrafya ile ilgili derslere devam etmek üzere Amerika Birleşik Deoletleri'ne gitmiştir.

Hocamız, 1966 yılında Fakültemizde Iktisadi Coğrafya Doçenti; 1977 yılında da profesör olmuş; daha sonra da 1997 yılında 67 yaş stnırınt doldurduğundan Fakültemizden emekliye ayrılmıştır.

Hemen belirtmek isterim ki, merhum Hocamı, emekliye ayrlmıs olmasına rağmen, her gün Fakültemize, mesleğe yeni başlamış̧asına, ayn heyecanla geliyor ve derslerine devam ediyordu.

Franszza ve Ingilizce bilen Hocamız, Sanayi Iktisadi, Temel Kaynaklar Ekonomisi, Iktisadi Coğrafya konulannda ders veriyordu. Bu konularda yayınlanmış makaleleri ve kitaplan vardt. Yaşantısında en önem verdiklerinin başında öğrencileri gelen, binlerce öğrenciyi yetiştiren Hocamızın önemli bir özelliği derslerine muntazaman deoam eden hiçbir öğrencisine seksenin altinda not vermemesiydi. 
Karaoğlan kơyünü bizlere çeşitli yönleriyle tanıtan Hocam gerçekten çok renkli bir simaydı.

Her şeyden önce Ülkemizin coğrafyast, enerji kaynaklan üzerinde çalıs̆tığı için enerji tasarrufuna inanılmaz bir önem verir, herkesi bu konuda bilinçlendirmeye çalışırdı. Fakülte'nin herhangi bir yerinde, bir odanın elektriklerinin sönük olması oradan Prof. Demir'in geçtiğinin göstergesiydi. Zaten, hareketliliği ve canlılığı ile Fakilltemizin her kössesindeydi; her an karşımıza çıkardı.

Kendisi ile ilgili diğer önemli bir husus da özel uğraşlaryydı. Gemi modelleri, tablolan ve maketleri onun yaşantısının önemli bir parçasıydı. Yaptığı maketlerle iki defa Dil ve Tarih-Coğrafya Fakültesi'nde sergi açmıştı. Ankara Gemi Modelleri ve Maketçiler Dermeği'nin kurucu üyeleri arasindaydi.

Prof. Demir Hocam da, daha önce aramızdan aynlan hocalarmmtz gibi, akademik çalışmalan, eserleri ve renkli kişiliği ile Mülkiye Tarihi'nde yerini almıştır. Kendisini çok arayacă̆ız, çok ozleyeceğiz. 